\title{
High Glucose Induces Mouse Mesangial Cell Overproliferation via Inhibition of Hydrogen Sulfide Synthesis in a TLR-4- Dependent Manner
}

\author{
Tao Ding Wei Chen Juan Li Jiarong Ding Haiyan Hu Xiaobin Mei \\ Department of Nephrology, Shanghai Changhai Hospital Affiliated to Second Military Medical \\ University, Shanghai, China
}

\section{Key Words}

Hydrogen sulfide $\cdot$ High glucose $・$ Mesangial cells $・$ TLR4

\begin{abstract}
Background/Aims: Overproliferation of mesangial cells was believed to play an important role in the progress of diabetic nephropathy, one of the primary complications of diabetes. Hydrogen sulfide $\left(\mathrm{H}_{2} \mathrm{~S}\right)$, a well-known and pungent gas with the distinctive smell of rotten eggs, was discovered to play a protective role in diabetic nephropathy. Methods: MTT assay was used to examine the viability of mesangial cells. Small interfering RNA was used to knock down the expression of TLR4 while specific inhibitor LY294002 to suppress the function of PI3K. $\mathrm{H}_{2} \mathrm{~S}$ generation rate was determined by a $\mathrm{H}_{2} \mathrm{~S}$ micro-respiration sensor. Results: Glucose of $25 \mathrm{mM}$ induced significant mesangial cells proliferation, which was accomplished by significantly inhibited endogenous $\mathrm{H}_{2} \mathrm{~S}$ synthesis. And exogenous $\mathrm{H}_{2} \mathrm{~S}$ treatment by NaHS markedly mitigated the overproliferation of mouse mesangial cells. Furthermore, it was found that $\mathrm{H}_{2} \mathrm{~S}$ deficiency could result in TLR4 activation. And $\mathrm{H}_{2} \mathrm{~S}$ supplementation remarkably inhibited TLR4 expression and curbed the mesangial cell overproliferation. Besides, PI3K/ Akt pathway inhibition also significantly ameliorated the cell overproliferation. Conclusion: High glucose $(H G)$ induces mouse mesangial cell overproliferation via inhibition of hydrogen sulfide synthesis in a TLR-4-dependent manner. And PI3K/Akt pathway might also play a vital part in the HG-induced mesangial cell overproliferation.

\section{Introduction}

Diabetes mellitus, a common chronic metabolic disease, is characteristic of a group of disorders in hemorheology, microcirculation and cellular metabolism, and could lead to ischemia, hypoxia, tissue hydropsia and more severely end-organ irreversible damage. Nephropathy is one of the leading causes of mortality in diabetes complication, which is featured by overproliferation of mesangial cells. The current paper focused on the potential 
mechanism underlying the overproliferation of mesangial cells, and aimed to provide a new potential target for the prevention and treatment of diabetic nephropathy.

Previous studies have shown that high plasma glucose in diabetes could result in reversible changes in some related genes and phenotypes. Mesangiolysis and exuberant mesangial repair then develop, ultimately resulting in marked increase in mesangial matrix $[1,2]$. However, the involved mechanisms and pathways are not yet fully elucidated.

Hydrogen sulfide $\left(\mathrm{H}_{2} \mathrm{~S}\right)$ is a well-known and pungent gas with the distinctive smell of rotten eggs discovered to be synthesized enzymatically in mammalian and human tissues. The prior studying about hydrogen sulfide to its discovery was concentrated on the resulted air/water pollution and the toxicity/inhibition in central nervous system and respiration system. Since its discover in mammalian in 1980s, hydrogen sulfide was shown to be take effect in various physiology and pathways involved in hippocampus, digestion and vascular smooth muscles [2, 3].

In mammalian and human tissues, the bulk of endogenous $\mathrm{H}_{2} \mathrm{~S}$ synthesis appears to be from the PLP (pyridoxal-5'-phosphate)-dependent enzymes cystathionine- $\gamma$-lyase (CSE) and cystathionine- $\beta$-synthase (CBS) via the amino acids cysteine, homocysteine and cystathionine [4]. It been widely suggested that the expression of CSE and CBS in rodents and humans showed a marked degree of tissue specificity. The current literature consensus was that CBS was the predominant source of $\mathrm{H}_{2} \mathrm{~S}$ in the brain and nervous tissue, and that in the vasculature (e.g. smooth muscle and endothelium) CSE was the major source of $\mathrm{H}_{2} \mathrm{~S}$ [2]. It also shares other similarities with carbon monoxide (CO) and nitric oxide (NO) which are both well accepted gasotransmitters, in that they exert biological effects at low concentrations, toxic effects at high concentrations [2-4]. Due to their wide biological applications, the gasotransmitters were not yet clearly elucidated in the receptors and functioning mechanism [5].

Hydrogen sulfide was demonstrated to be regulating cellular proliferation. $\mathrm{H}_{2} \mathrm{~S}$ is the first identified endogenous gaseous opener of ATP-sensitive $\mathrm{K}^{+}$channels in vascular smooth muscle cells. Through the activation of ATP-sensitive $\mathrm{K}^{+}$channels, $\mathrm{H}_{2} \mathrm{~S}$ lowers blood pressure, protects the heart from ischemia and reperfusion injury, inhibits insulin secretion in pancreatic $\beta$ cells, and exerts anti-inflammatory, anti-nociceptive and anti-apoptotic effects. Yang et al. also showed that genetic deletion of CSE by which $\mathrm{H}_{2} \mathrm{~S}$ is physiologically generated in mice markedly reduces $\mathrm{H}_{2} \mathrm{~S}$ levels in the serum, heart, aorta, and other tissues [6-8]. Interestingly, $\mathrm{H}_{2} \mathrm{~S}$ was reported by many to play an important role in diabetic nephropathy [9-12]. Hence it was implied that exogenous $\mathrm{H}_{2} \mathrm{~S}$ might attenuate the progression of diabetic nephropathy by inhibiting the mesangial cell proliferation.

Toll-like receptor (TLR) family was a well-accepted group of pathogen-associated molecular patterns (PAMPs) receptors [13]. Moreover, it has been proved that TLRs could trigger aseptic inflammation by recognizing various endogenous cellular components, such as heat shock protein 90 and hyaluronic acid $[14,15]$. More importantly, TLR4 seemed to be mediating the pathophysiology in diabetes: type 2 diabetic subjects had significantly increased TLR4 mRNA, and related ligands in monocytes compared with control subjects $[16,17]$; in vitro, high glucose induces toll-like receptor expression in human monocytes [18]. To investigate the involvement of TLR4 in the diabetic mesangial cell overproliferation, we adopted TLR4-defecient model using siRNA technique in vitro and gene knock-out in vivo. It was found that high glucose induced the mRNA expression of TLR4 in a concentrationdependent way, which was attenuated by siRNA knock-down of TLR4 in vitro and abated by TLR4 knock-out in C3H/HeouJ mice. More interestingly, expression of CBS/CSE was augmented after TLR4 inhibition in vitro and in vivo.

Therefore, we hypothesized that TLR4 overexpression led to a lacking of endogenous hydrogen sulfide, resulting in the mesangial cell overproliferation in diabetic nephropathy. Hence certain techniques would be adopted to demonstrate our hypothesis like siRNA transfection (CSE), genetic co-immunoprecipitation etc.

\section{KARGER}




\section{Cellular Physiology Cell Physiol Biochem 2017;41:1035-1043 \\ \begin{tabular}{ll|l} 
and Biochemistry Published onlIne: February 22, 2017 & $\begin{array}{l}\text { (c) } 2017 \text { The Author(s). Published by S. Karger AG, Basel } \\
\text { www.karger.com/cpb }\end{array}$ \\
\hline
\end{tabular} \\ Ding et al.: Hydrogen Sulfide and High Glucose-Induced Mesangial Cell Overproliferation}

\section{Materials and Methods}

\section{Cell culture and treatment}

Mouse mesangial cells (purchased from the Shanghai Chinese Academy of Sciences) were culture in low-glucose DMEM medium supplemented with $10 \% \mathrm{FBS}$ at $37^{\circ} \mathrm{C}, \mathrm{CO}_{2}$ incubator according to the manufacturer's instructions. Cells at a density of $1 \times 10^{5} / \mathrm{mL}$ were seeded in 6 -well plates to reach $80-90 \%$ confluence. $0.25 \%$ trypsin with $0.03 \%$ EDTA was used to digest the cells. The normal glucose group was treated with $5.5 \mathrm{mM}$ glucose while the high glucose $25 \mathrm{mM}, 30 \mathrm{mM}, 35 \mathrm{mM}$ and $40 \mathrm{mM}$. After overnight fasting, cells were incubated with normal or high glucose for 24 hours. NaHS (Sigma) was added to the mesangial cells at the meantime of glucose, at different concentrations of $5 \mu \mathrm{M}, 10 \mu \mathrm{M}, 30 \mu \mathrm{M}, 50 \mu \mathrm{M}$ and $100 \mu \mathrm{M}$. The proliferation of mesangial cells was examined by MTT (3-[4, 5-dimethylthiazol -2-yl] - 2, 5diphenyl tetrazolium bromide, Sigma Aldrich) assay as previously described [19, 20].

\section{RNA interference and PI3K inhibition}

The small interfering RNA for TLR4 was obtained from Santa Cruz (sc-40261). Transfection of siRNA to murine mesangial cells was performed using siPORT NeoFx transfection agent (Ambion) according to the manufacturer's instruction. LY294002, (2-(4-morpholinyl)-8-phenyl-4H-1-benzopyran-4-one) was used as a specific inhibitor of phosphatidylinositol 3-kinase [21].

\section{Real-time $\mathrm{H}_{2} \mathrm{~S}$ production determination}

$\mathrm{H}_{2} \mathrm{~S}$ production was determined real-time as previously described [20,22]. Briefly, cells were collected in PBS containing protease inhibitor (2 $\mathrm{mM}$ phenylmethylsulfonyl fluoride, $1 \mathrm{mM}$ sodium orthovanadate, and $10 \mathrm{mg} / \mathrm{ml}$ aprotinin) and homogenized for $15 \mathrm{~s}$ on ice. Then the suspension was centrifuged at 5000 rpm for $5 \mathrm{~min}$, after which the supernatants were placed into a temperature-controlled micro-respiration chamber (Unisense) to measure $\mathrm{H}_{2} \mathrm{~S}$ production using a miniaturized $\mathrm{H}_{2} \mathrm{~S}$ micro-respiration sensor (Model $\mathrm{H}_{2} \mathrm{~S}$-MRCh; Unisense) coupled with a Unisense PA2000 amplifier. The $\mathrm{H}_{2} \mathrm{~S}$ production was standardized by total protein concentration determined by modified Bradford assay.

\section{Western blot analysis}

Western blot analysis was conducted as previous described. Mouse mesangial cells were homogenized

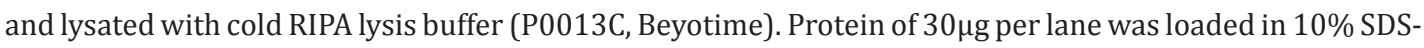
PAGE followed by transfer to nitrocellulose membranes. Blocked with 5\% skim milk powder dissolved in PBS, the bolts were incubated with antibodies against overnight at $4^{\circ} \mathrm{C}$ at a dilution of 1:1000. The primary antibody used in the experiment were TLR4 (25) (Santa Cruz, sc-293072), CSE (CTH P-15) (Santa Cruz, sc-131905), phosp-Akt (Ser473, Santa Cruz, sc-293125), Akt (Santa Cruz, sc-5298), phosphor-PI3K (Santa Cruz, sc-130211), and PI 3-kinase C2 $\alpha$ Antibody (H-300, Santa Cruz, sc-67306). Secondary horseradish peroxidase-conjugated antibody was applied to the membrane for $1 \mathrm{~h}$ at room temperature. The enhanced chemiluminescence western blotting detection system (Santa Cruz) was used to visualize immunoreative proteins. A GeneGnome HR scanner was adopted to quantify the bolts of the membranes by GeneTools Software. Actin expression was obtained to quantify the relative protein expression level.

\section{Statistical analysis}

Data were expressed as means \pm SEM. Two-tailed Student's $t$ test was adopted for the compare of statistical significance between only two groups, while one-way analysis of variance (ANOVA) for among more than two groups followed by post hoc the Student-Newman-Keuls test. SPSS 16.0 (SPSS, Inc.) was used and less-than-0.05 P value was considered significant [23].

\section{Results}

High glucose inhibited the synthesis of endogenous $\mathrm{H}_{2} \mathrm{~S}$ and induced the overproliferation in mouse mesangial cells

First, we investigated the effect of glucose on cell viability on mouse mesangial cells incubated in $5 \mathrm{mM}$ (control), $20 \mathrm{mM}, 25 \mathrm{mM}$ and $30 \mathrm{mM}$ glucose. It was found that high glucose incubation resulted in 
significant overproliferation of the renal mesangial cells in mice, in a concentration-independent manner (Fig. 1A). Glucose of $25 \mathrm{mM}$ induced the high increment in the cell viability. Then the endogenous $\mathrm{H}_{2} \mathrm{~S}$ synthesis was assessed in mouse mesangial cells cultured in high glucose. Western blot analysis detected significantly decreased expression of CSE in $20 \mathrm{mM}, 25 \mathrm{mM}$ and $30 \mathrm{mM}$ glucose groups compared to control groups (Fig. 1C). Besides, the $\mathrm{H}_{2} \mathrm{~S}$ generation rate was significantly reduced in cells incubated in $25 \mathrm{mM}$ and $30 \mathrm{mM}$ glucose compared to control (Fig. 1B). At last, $\mathrm{H}_{2} \mathrm{~S}$ supplementation was conducted via NaHS administration. It was found that NaHS treatment significantly curbed the mesangial cell overproliferation.

TLR4 activation was found to be involved in the high glucose-induced mesangial cell overproliferation

Western blot showed that high glucose $(25 \mathrm{mM})$ incubation significantly activated the expression of TLR4 (Fig. 1D). Downregulation of TLR4 by siRNA could reverse the overproliferation of mesangial cells in mice (Fig. 2C). Interestingly, silencing of CSE also significantly increased the TLR4 expression in mouse mesangial cells (Fig. 2B); NaHS treatment could significantly inhibit the TLR4 activation and curbed the cell overproliferation (Fig. 2B). Besides, TLR4 downregulation did not significantly alter the inhibition of the CSE expression induced by high glucose (Fig. 2A). However, TLR4 silencing could markedly abolish the cell overproliferation resulted from CSE downregulation. These results implied that TLR4 might be in the downstream of CSE pathway in the hyperglycemia-induced mesangial cell overproliferation.

Downregulation of TLR4 inhibited PI3K-Akt pathway and curbed the overproliferation of mouse mesangial cells

We then investigate the effect of TLR4 on PI3K-Akt pathway in mesangial cells. Western blot analysis showed that the phosphorylation of PI3K and Akt was significantly enhanced by hyperglycemia and reduced to normal level after TLR4 knock-down, although the total expression of PI3K and Akt remained unchanged (Fig. 3A and B). Inhibition of PI3K by LY294002 also significantly mitigated high-glucose-induced cell proliferation as was demonstrated in Fig. 3C.

Fig. 1. High glucose (HG) induced significant overproliferation of mouse mesangial cells, which could be partly attributed to endogenous $\mathrm{H}_{2} \mathrm{~S}$ synthesis deficiency or TLR4 activation. (A) HG induced significant overproliferation in mouse mesangial cells. Mannitol treatment of $25 \mathrm{mM}$ did not significantly alter the viability in mouse mesangial cells. (Values were mean \pm SEM; ${ }^{*} P<0.05,{ }^{* *} P<0.01$ vs. $5 \mathrm{mM}$ glu; ${ }^{\# \#} P<0.01$ vs. 25 mM glu; $n=4$ ). (B) $\mathrm{H}_{2} \mathrm{~S}$ generation rate was significantly reduced by $\mathrm{HG}$ treatment of $25 \mathrm{mM}$ and 30
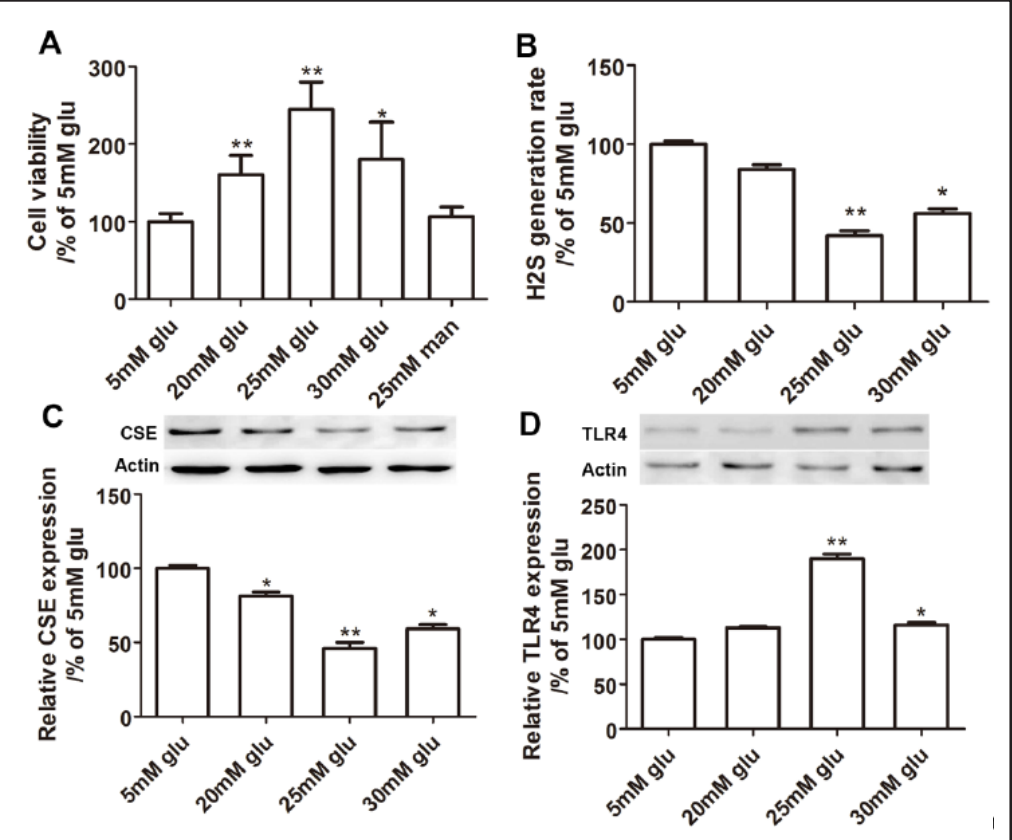
$\mathrm{mM}$, compared to $5 \mathrm{mM}$ glu. (Values were mean $\pm \mathrm{SEM}$; ${ }^{*}<<0.05{ }^{* *} P<0.01$ vs. $5 \mathrm{mM}$ glu; $\mathrm{n}=4$ ). (C) CSE expression was significantly reduced by HG treatment in a concentration- independent manner. (Values were mean $\pm \mathrm{SEM}$; ${ }^{*} P<0.05$, ${ }^{* *} P$ $<0.01$ vs. $5 \mathrm{mM}$ glu; $\mathrm{n}=4$ ). (D) TLR4 expression was significantly reduced by HG treatment of $25 \mathrm{mM}$ and 30mM. (Values were mean \pm SEM; ${ }^{*} P<0.05$, ${ }^{* *} P<0.01$ vs. $5 \mathrm{mM}$ glu; $\mathrm{n}=4$ ).

\section{KARGER}


Fig. 2. CSE inhibition-induced TLR4 activation was possibly involved in the mesangial cell overproliferation resulted by HG. (A) TLR4 suppression did not alter the CSE expression in mouse mesangial cells treated by high glucose. (Values were mean $\pm \mathrm{SEM} ;{ }^{* *} P<0.01$ vs. $5 \mathrm{mM}$ glu + con siR; $\mathrm{n}$ = 4). (B) Inhibition of CSE resulted in activation of TLR4, which was reversed by NaHS treatment. (Values were mean $\pm \mathrm{SEM}$; ${ }^{*} P<0.05$ vs. con siR; ${ }^{\#} P<$ 0.05 vs. CSE siR; $n=4$ ). (C) Silencing of TLR4 significantly reversed the cell overproliferation induced by HG. (Values were mean

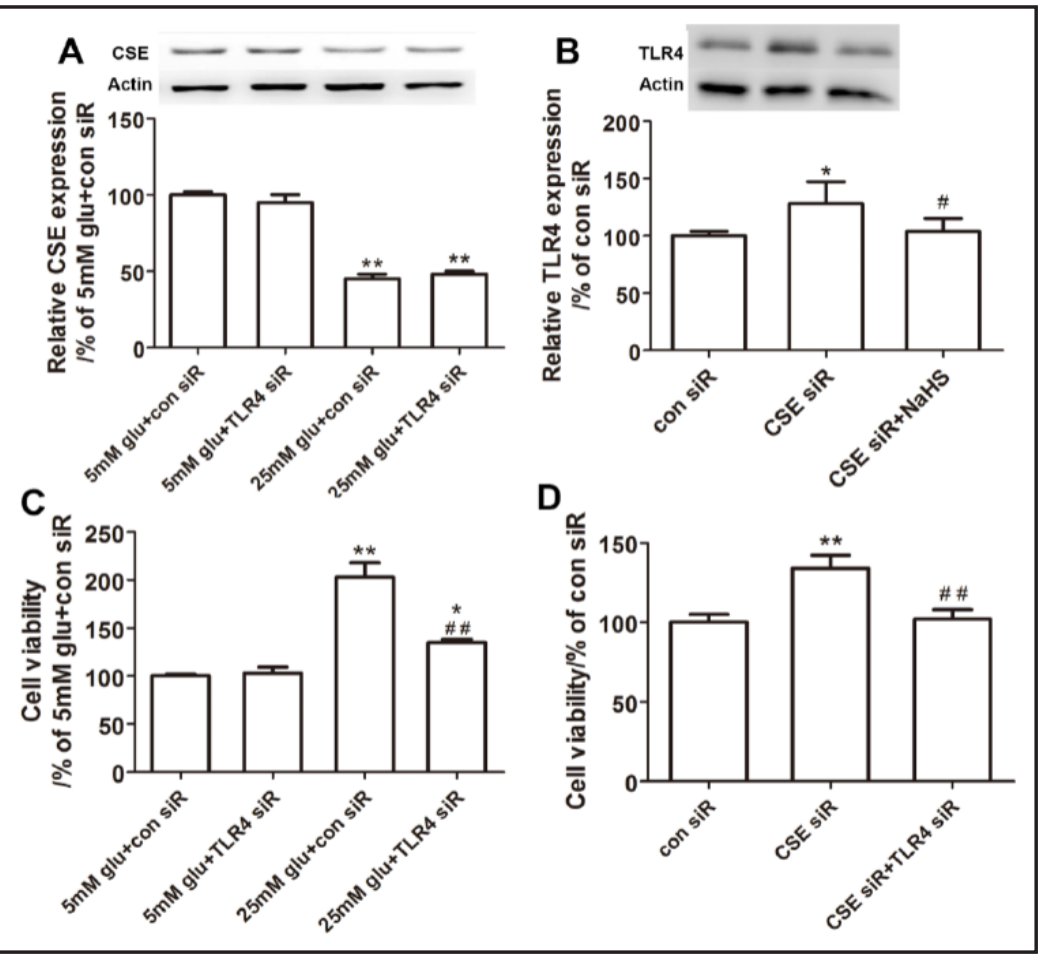
\pm SEM; ${ }^{*} P<0.05,{ }^{* *} P<0.01$ vs. $5 \mathrm{mM}$ glu + con siR; ${ }^{\#} P<0.01$ vs. $25 \mathrm{mM}$ glu + con siR; $\mathrm{n}=4$ ). (D) TLR4 suppression significantly curbed the mesangial cell overproliferation induced by CSE silencing. (Values were mean \pm SEM; ${ }^{* *} P<0.01$ vs. $5 \mathrm{mM}$ glu + con $\operatorname{siR}^{*}{ }^{\# \#} P<0.01$ vs. $25 \mathrm{mM}$ glu + con siR; $\mathrm{n}=4$ ).

Fig. 3. Inhibition of PI3K pathway significantly suppressed HG-induced mesangial cell proliferation in a TLR4-dependent way. (A, B) HG led to significant increase in the expression of PI3K/Akt in mouse mesangial cells, which was down-modulated by TLR4 silencing. (Values were mean \pm SEM; ${ }^{* *} P<0.01$ vs. $5 \mathrm{mM}$

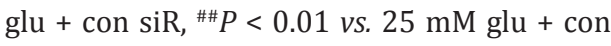
siR; $n=4)$. (C) Inhibition of PI3K significantly curbed the mesangial cell overproliferation induced by HG treatment. (Values were mean \pm SEM; ${ }^{* *} P<0.01$ vs. $5 \mathrm{mM}$ glu; ${ }^{\# \#} P<0.01$ vs. 25 mM glu; $\mathrm{n}=4$ ).

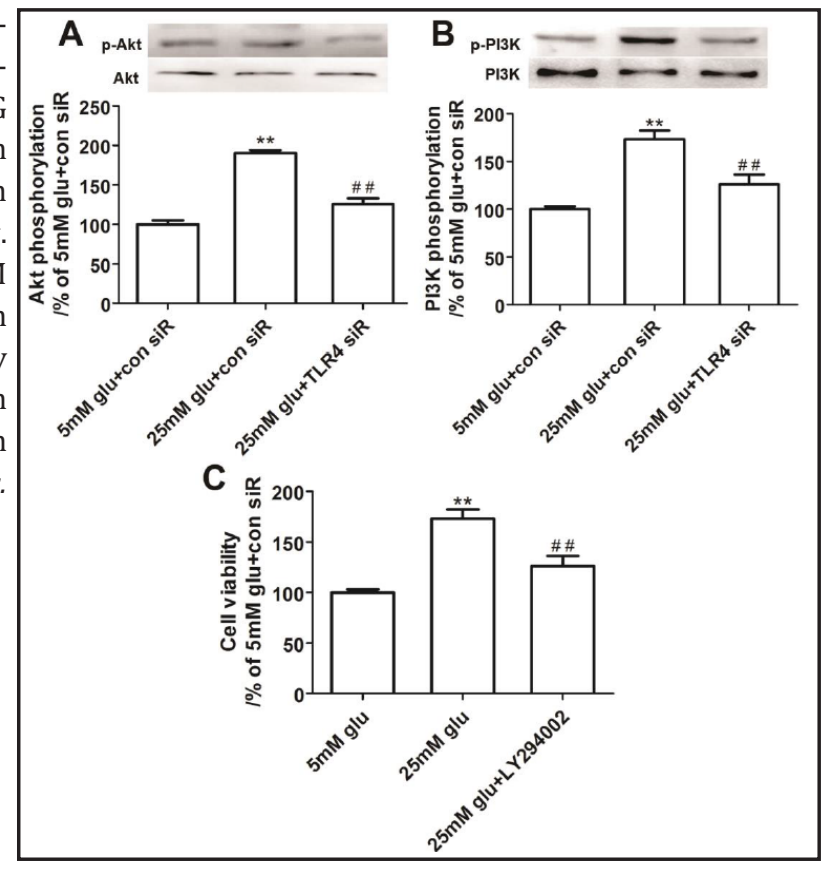

\section{Discussion}

The main finding of the current paper was that diabetic renal lesions could be induced by the downregulation of hydrogen sulfide which was dependent of augmented TLR4 expression and reduced $\mathrm{H}_{2} \mathrm{~S}$ synthesis. In addition, TLR4-mediated PI3K-Akt pathway activation partially contributed to the pathophysiology of diabetic nephropathy. 
For several centuries, hydrogen sulfide $\left(\mathrm{H}_{2} \mathrm{~S}\right)$ had been known to be highly toxic. However, more recently $\mathrm{H}_{2} \mathrm{~S}$ has been recognized as mediating a wide range of physiological effects. Nitric oxide (NO) is a gas with biological and regulatory properties and a very short half-life (few seconds), whose characters are shared by $\mathrm{H}_{2} \mathrm{~S}$. Like NO, $\mathrm{H}_{2} \mathrm{~S}$ synthesis and bioavailability were vital to the physiological and pathophysiological processes. $\mathrm{H}_{2} \mathrm{~S}$ is a highly lipophilic molecule able to freely penetrate the membranes of cells of all types by diffusion and without the requirement for specialized membrane transporters [24]. Through its presence and enzymatic production, $\mathrm{H}_{2} \mathrm{~S}$ has gained attention for its signaling capabilities as important gasotransmitters like nitric oxide (NO) and carbon monoxide (CO) [4].

Accumulating evidence has shown that upregulation of $\mathrm{H}_{2} \mathrm{~S}$ exerts protective effect on diabetes-induced damages such as cardiac fibrosis, glomerular podocyte injury, wound healing impairment etc. [25-35]. Besides, a reduction in hydrogen sulfide $\left(\mathrm{H}_{2} \mathrm{~S}\right)$ has been suggested to play a vital role in diabetic vascular complications including diabetic nephropathy [29]. It was demonstrated that lower concentrations of $\mathrm{H}_{2} \mathrm{~S}$ were responsible for the development and progression of diabetic nephropathy [36]. $\mathrm{H}_{2} \mathrm{~S}$ generation in Type 2 diabetes with nephropathy is inversely associated with the CSE/CBS mRNA expression. A disturbed $\mathrm{H}_{2} \mathrm{~S}$ metabolism is present in diabetes associated with nephropathy [37]. Furthermore, $\mathrm{H}_{2}^{2} \mathrm{~S}$ was reported to have a neuroprotective effect against the cognitive diseases [38-40]. The proposed mechanisms underlying the protective effect of $\mathrm{H}_{2} \mathrm{~S}$ involved oxidative stress [25] and autophagy [41].

Diabetic nephropathy was a leading cause of end-stage kidney disease worldwide. Marked mesangial matrix expansion was characteristic as renal lesions in diabetic patients [42]. Not only mesangial cells, upregulated hydrogen sulfide could also attenuate high glucose-induced mouse podocyte (MPC) injury [30]. However, the exact mechanisms and pathways by which $\mathrm{H}_{2} \mathrm{~S}$ exerts its multitude of effects are not yet fully understood. Our results have demonstrated that overproliferation of mouse mesangial cells could be inhibited by $\mathrm{H}_{2} \mathrm{~S}$ upregulation through addition of an exogenous donor (NaHS) or overexpression of CSE/CBS.

TLRs, one family of pathogen-associated molecular patterns (PAMPs) receptors, are integral membrane glycoproteins with cytoplasmic tails, and play a role in the early recognition and host defense against pathogenic microorganisms [43, 44]. TLR-4 also recognizes other. TLR-4, like other TLRs, is able to recognize endotoxin (LPS) and microbial molecules (glycolipids, respiratory syncytial virus fusion protein and heat shock proteins) and endogenous damage-induced tissue molecules producing intracellular signals responsively $[45,46]$. To note, hyperglycemia was shown to induce TLR4 expression. Pahwa et al. found that TLR4 mediate hyperglycemia induced macrovascular aortic endothelial cell inflammation and perturbation of the endothelial glycocalyx [47]. And high glucose could also induce and activate TLR4 in endothelial cells of diabetic retinopathy [48, 49]. The present study demonstrated that TLR4 knock-down curbed the abnormal proliferation of mesangial cells induced by hyperglycemia, which was in accordance with the others' reports.

Interesting, TLR4 was reported to be associated with $\mathrm{H}_{2} \mathrm{~S}$ synthesis and bioavailability. Tamizhselvi et al. [50] reported that $\mathrm{H}_{2} \mathrm{~S}$ may up-regulate the TLR4 pathway via substance $\mathrm{P}$. In accordance, our in-vitro experiment showed that the downregulation of $\mathrm{H}_{2} \mathrm{~S}$ could markedly activate the TLR4 expression in the mouse mesangial cells. Vice versa, TLR4 was reported to upregulate CBS expression through NF- $\kappa B$ activation in rat [51]. Zheng et al. found that compared with their wide-type counterparts, TLR4 knockout mice showed elevated expression of $\mathrm{H}_{2} \mathrm{~S}$-synthesizing enzyme CSE, therefore abolishing the inflammation effect of lipopolysaccharide [52].

The phosphatidylinositol-4,5-bisphosphate 3-kinase/protein kinase B (PI3K/Akt) signaling pathway was suppressed in diabetes[53,54]. Our results showed that TLR4 interfering suppressed the PI3K/Akt pathway, mitigating the abnormal mesangial cell proliferation. The present study demonstrated that the effect of $\mathrm{H}_{2} \mathrm{~S}$ against hyperglycemiainduced mesangial cell proliferation might be associated with the down-regulation of the PI3K/Akt signaling pathway. More evidences had shown that PI3K/Akt signaling pathway participated the physiological effect of $\mathrm{H}_{2} \mathrm{~S}$ [55-57].

\section{KARGER}




\section{Cellular Physiology Cell Physiol Biochem 2017;41:1035-1043

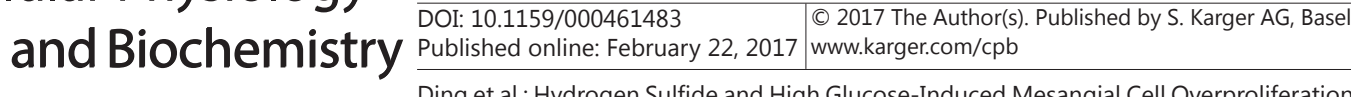

In summary, we found that $\mathrm{HG}$ inhibited the synthesis of endogenous $\mathrm{H}_{2} \mathrm{~S}$ and induced the overproliferation in mouse mesangial cells; TLR4 activation was involved in the HGinduced mesangial cell overproliferation; downregulation of TLR4 inhibited PI3K-Akt pathway and curbed the overproliferation of mouse mesangial cells. It was concluded that high glucose could induce mouse mesangial cell overproliferation via inhibition of hydrogen sulfide synthesis in a TLR-4-dependent manner.

\section{Acknowledgments}

This work was supported by Research and innovation project of Shanghai Municipal Education Commission (13ZZ063).

\section{Disclosure Statement}

None.

\section{References}

1 Bishara NB, Triggle CR, Hill MA: Cytochrome p450 products and arachidonic acid-induced, non-storeoperated, ca2+ entry in cultured bovine endothelial cells. Endothelium 2005;12:153-161.

$\checkmark 2$ Whiteman M, Le Trionnaire S, Chopra M, Fox B, Whatmore J: Emerging role of hydrogen sulfide in health and disease: Critical appraisal of biomarkers and pharmacological tools. Clin Sci (Lond) 2011;121:459-488.

-3 Medani M, Collins D, Docherty NG, Baird AW, O'Connell PR, Winter DC: Emerging role of hydrogen sulfide in colonic physiology and pathophysiology. Inflamm Bowel Dis 2011;17:1620-1625.

4 King AL, Lefer DJ: Cytoprotective actions of hydrogen sulfide in ischaemia-reperfusion injury. Exp Physiol 2011;96:840-846.

5 Wang R: Gasotransmitters: Growing pains and joys. Trends Biochem Sci 2014;39:227-232.

6 Tang G, Wu L, Wang R: Interaction of hydrogen sulfide with ion channels. Clin Exp Pharmacol Physiol 2010;37:753-763.

7 Yang G, Wu L, Jiang B, Yang W, Qi J, Cao K, Meng Q, Mustafa AK, Mu W, Zhang S, Snyder SH, Wang R: H2s as a physiologic vasorelaxant: Hypertension in mice with deletion of cystathionine gamma-lyase. Science 2008;322:587-590.

8 Yang G, Wu L, Bryan S, Khaper N, Mani S, Wang R: Cystathionine gamma-lyase deficiency and overproliferation of smooth muscle cells. Cardiovasc Res 2010;86:487-495.

-9 Ahmad FU, Sattar MA, Rathore HA, Abdullah MH, Tan S, Abdullah NA, Johns EJ: Exogenous hydrogen sulfide (h2s) reduces blood pressure and prevents the progression of diabetic nephropathy in spontaneously hypertensive rats. Renal failure 2012;34:203-210.

10 Yamamoto J, Sato W, Kosugi T, Yamamoto T, Kimura T, Taniguchi S, Kojima H, Maruyama S, Imai E, Matsuo $\mathrm{S}$, Yuzawa Y, Niki I: Distribution of hydrogen sulfide (h(2)s)-producing enzymes and the roles of the h(2)s donor sodium hydrosulfide in diabetic nephropathy. Clin Exp Nephrol 2013;17:32-40.

-11 Szabo C: Roles of hydrogen sulfide in the pathogenesis of diabetes mellitus and its complications. Antioxid Redox Signal 2012;17:68-80.

12 Zhou X, Feng Y, Zhan Z, Chen J: Hydrogen sulfide alleviates diabetic nephropathy in a streptozotocininduced diabetic rat model. J Biol Chem 2014;289:28827-28834.

13 Tidswell M: Toll-like receptor-4 antagonist eritoran tetrasodium for severe sepsis. Expert Rev Anti Infect Ther 2011;9:14.

14 Xu C, Liu J, Hsu LC, Luo Y, Xiang R, Chuang TH: Functional interaction of heat shock protein 90 and beclin 1 modulates toll-like receptor-mediated autophagy. FASEB J 2011;25:2700-2710.

15 Kim BS, Lim SW, Li C, Kim JS, Sun BK, Ahn KO, Han SW, Kim J, Yang CW: Ischemia-reperfusion injury activates innate immunity in rat kidneys. Transplantation 2005;79:1370-1377. 


\section{Cellular Physiology Cell Physiol Biochem 2017;41:1035-1043 and Biochemistry DOI: 10.1159/000461483 201 P 2017 The Author(s). Published by S. Karger AG, Basel

16 Jain SK, Rains JL: Toll-like receptor-4 and vascular inflammation in diabetes: editorial. Cytokine 2011;55:446-447.

17 Dasu MR, Devaraj S, Park S, Jialal I: Increased toll-like receptor (tlr) activation and tlr ligands in recently diagnosed type 2 diabetic subjects. Diabetes Care 2010;33:861-868.

-18 Dasu MR, Devaraj S, Zhao L, Hwang DH, Jialal I: High glucose induces toll-like receptor expression in human monocytes: mechanism of activation. Diabetes 2008;57:3090-3098.

19 Liu S, Zhu X, Liu Y, Wang C, Wang S, Tang X, Ni X: Endotoxin tolerance of adrenal gland: Attenuation of corticosterone production in response to lipopolysaccharide and adrenocorticotropic hormone. Crit Care Med 2011;39:518-526.

20 Wang CN, Liu YJ, Duan GL, Zhao W, Li XH, Zhu XY, Ni X: Cbs and cse are critical for maintenance of mitochondrial function and glucocorticoid production in adrenal cortex. Antioxid Redox Signal 2014;21:2192-2207.

21 Vlahos CJ, Matter WF, Hui KY, Brown RF: A specific inhibitor of phosphatidylinositol 3-kinase, 2-(4-morpholinyl)-8-phenyl-4h-1-benzopyran-4-one (ly294002). J Biol Chem 1994;269:5241-5248.

22 Zhu X, Tang Z, Cong B, Du J, Wang C, Wang L, Ni X, Lu J: Estrogens increase cystathionine-gamma-lyase expression and decrease inflammation and oxidative stress in the myocardium of ovariectomized rats. Menopause 2013;20:1084-1091.

23 Wang CN, Duan GL, Liu YJ, Yu Q Tang XL, Zhao W, Li XH, Zhu XY, Ni X: Overproduction of nitric oxide by endothelial cells and macrophages contributes to mitochondrial oxidative stress in adrenocortical cells and adrenal insufficiency during endotoxemia. Free Radic Biol Med 2015;83:31-40.

24 Mathai JC, Missner A, Kugler P, Saparov SM, Zeidel ML, Lee JK, Pohl P: No facilitator required for membrane transport of hydrogen sulfide. Proc Natl Acad Sci USA 2009;106:16633-16638.

-25 Zheng D, Dong S, Li T, Yang F, Yu X, Wu J, Zhong X, Zhao Y, Wang L, Xu C, Lu F, Zhang W: Exogenous hydrogen sulfide attenuates cardiac fibrosis through reactive oxygen species signal pathways in experimental diabetes mellitus models. Cell Physiol Biochem 2015;36:917-929.

-26 Xiao T, Zeng O, Luo J, Wu Z, Li F, Yang J: Effects of hydrogen sulfide on myocardial fibrosis in diabetic rats: Changes in matrix metalloproteinases parameters. Biomed Mater Eng 2015;26:S2033-2039.

-27 Yang R, Jia Q Guo X, Liu X, Ma S, Gao Q Guan S: [protective effects of hydrogen sulfide on diaphragmatic muscle of type 1 diabetic rats and its anti-apoptotic mechanisms]. Zhong Nan Da Xue Xue Bao Yi Xue Ban 2015;40:1173-1178.

28 Zhang H, Zhuang XD, Meng FH, Chen L, Dong XB, Liu GH, Li JH, Dong Q, Xu JD, Yang CT: Calcitriol prevents peripheral rsc96 schwann neural cells from high glucose \& methylglyoxal-induced injury through restoration of cbs/h2s expression. Neurochem Int 2016;92:49-57.

29 Sen U, Pushpakumar S: Mini-review: Diabetic renal complications, a potential stinky remedy. Am J Physiol Renal Physiol 2016;310:F119-122.

-30 Liu Y, Zhao H, Qiang Y, Qian G, Lu S, Chen J, Wang X, Guan Q Liu Y, Fu Y: Effects of hydrogen sulfide on high glucose-induced glomerular podocyte injury in mice. Int J Clin Exp Pathol 2015;8:6814-6820.

-31 Xiao T, Luo J, Wu Z, Li F, Zeng O, Yang J: Effects of hydrogen sulfide on myocardial fibrosis and pi3k/akt1regulated autophagy in diabetic rats. Mol Med Rep 2016;13:1765-1773.

32 Huang CW, Moore PK: H2s synthesizing enzymes: Biochemistry and molecular aspects. Handb Exp Pharmacol 2015;230:3-25.

33 Wang G, Li W, Chen Q, Jiang Y, Lu X, Zhao X: Hydrogen sulfide accelerates wound healing in diabetic rats. Int J Clin Exp Pathol 2015;8:5097-5104.

-34 van den Born JC, Hammes HP, Greffrath W, van Goor H, Hillebrands JL, Complications DGIRTGDM: Gasotransmitters in vascular complications of diabetes. Diabetes 2016;65:331-345.

-35 Liang W, Chen J, Mo L, Ke X, Zhang W, Zheng D, Pan W, Wu S, Feng J, Song M, Liao X: Atp-sensitive k+ channels contribute to the protective effects of exogenous hydrogen sulfide against high glucose-induced injury in h9c2 cardiac cells. Int J Mol Med 2016;37:763-72.

-36 Li H, Feng SJ, Zhang GZ, Wang SX: Correlation of lower concentrations of hydrogen sulfide with atherosclerosis in chronic hemodialysis patients with diabetic nephropathy. Blood Purif 2014;38:188-194.

-37 Tessari P: Nitric oxide in the normal kidney and in patients with diabetic nephropathy. J Nephrol 2015;28:257-268.

-38 Liu Y, Liao S, Quan H, Lin Y, Li J, Yang Q: Involvement of microrna-135a-5p in the protective effects of hydrogen sulfide against parkinson's disease. Cell Physiol Biochem 2016;40:18-26. 


\section{Cellular Physiology Cell Physiol Biochem 2017;41:1035-1043 and Biochemistry DOI: 10.1159/000461483 2010 (0) 2017 The Author(s). Published by S. Karger AG, Basel

-39 Yu Q, Lu Z, Tao L, Yang L, Guo Y, Yang Y, Sun X, Ding Q: Ros-dependent neuroprotective effects of nahs in ischemia brain injury involves the parp/aif pathway. Cell Physiol Biochem 2015;36:1539-1551.

40 Wei X, Zhang B, Zhang Y, Li H, Cheng L, Zhao X, Yin J, Wang G: Hydrogen sulfide inhalation improves neurological outcome via nf-kappab-mediated inflammatory pathway in a rat model of cardiac arrest and resuscitation. Cell Physiol Biochem 2015;36:1527-1538.

41 Xiao J, Zhu X, Kang B, Xu J, Wu L, Hong J, Zhang Y, Ni X, Wang Z: Hydrogen sulfide attenuates myocardial hypoxia-reoxygenation injury by inhibiting autophagy via mtor activation. Cell Physiol Biochem 2015;37:2444-2453.

42 Kimmelstiel P, Wilson C: Intercapillary lesions in the glomeruli of the kidney. Am J Pathol 1936;12:83-98 87.

43 Ferrandon D, Imler JL, Hetru C, Hoffmann JA: The drosophila systemic immune response: Sensing and signalling during bacterial and fungal infections. Nat Rev Immunol 2007;7:862-874.

44 Akira S, Uematsu S, Takeuchi O: Pathogen recognition and innate immunity. Cell 2006;124:783-801.

45 Bryant CE, Spring DR, Gangloff M, Gay NJ: The molecular basis of the host response to lipopolysaccharide. Nat Rev Microbiol 2010;8:8-14.

46 Resman N, Vasl J, Oblak A, Pristovsek P, Gioannini TL, Weiss JP, Jerala R: Essential roles of hydrophobic residues in both md-2 and toll-like receptor 4 in activation by endotoxin. J Biol Chem 2009;284:1505215060.

47 Pahwa R, Nallasamy P, Jialal I: Toll-like receptors 2 and 4 mediate hyperglycemia induced macrovascular aortic endothelial cell inflammation and perturbation of the endothelial glycocalyx. J Diabetes Complications 2016;30:563-572.

48 Wang L, Wang J, Fang J, Zhou H, Liu X, Su SB: High glucose induces and activates toll-like receptor 4 in endothelial cells of diabetic retinopathy. Diabetol Metab Syndr 2015;7:89.

-49 Rajamani U, Jialal I: Hyperglycemia induces toll-like receptor-2 and -4 expression and activity in human microvascular retinal endothelial cells: Implications for diabetic retinopathy. J Diabetes Res 2014;2014:790902.

50 Tamizhselvi R, Shrivastava P, Koh YH, Zhang H, Bhatia M: Preprotachykinin-a gene deletion regulates hydrogen sulfide-induced toll-like receptor 4 signaling pathway in cerulein-treated pancreatic acinar cells. Pancreas 2011;40:444-452.

51 Yuan B, Tang WH, Lu LJ, Zhou Y, Zhu HY, Zhou YL, Zhang HH, Hu CY, Xu GY: Tlr4 upregulates cbs expression through nf-kappab activation in a rat model of irritable bowel syndrome with chronic visceral hypersensitivity. World J Gastroenterol 2015;21:8615-8628.

52 Zheng Y, Luo N, Mu D, Jiang P, Liu R, Sun H, Xiong S, Liu X, Wang L, Chu Y: Lipopolysaccharide regulates biosynthesis of cystathionine gamma-lyase and hydrogen sulfide through toll-like receptor-4/p38 and tolllike receptor-4/nf-kappab pathways in macrophages. In Vitro Cell Dev Biol Anim 2013;49:679-688.

53 Liu H, Liu HY, Jiang YN, Li N: Protective effect of thymoquinone improves cardiovascular function, and attenuates oxidative stress, inflammation and apoptosis by mediating the pi3k/akt pathway in diabetic rats. Mol Med Rep 2016;13:2836-2842.

54 Shum M, Bellmann K, St-Pierre P, Marette A: Pharmacological inhibition of s6k1 increases glucose metabolism and akt signalling in vitro and in diet-induced obese mice. Diabetologia 2016;59:592-603.

55 Dai HB, Xu MM, Lv J, Ji XJ, Zhu SH, Ma RM, Miao XL, Duan ML: Mild hypothermia combined with hydrogen sulfide treatment during resuscitation reduces hippocampal neuron apoptosis via nr2a, nr2b, and pi3k-akt signaling in a rat model of cerebral ischemia-reperfusion injury. Mol Neurobiol DOI:10.1007/s12035-0159391-z.

56 Gong D, Cheng HP, Xie W, Zhang M, Liu D, Lan G, Huang C, Zhao ZW, Chen LY, Yao F, Tan YL, Li L, Xia XD, Zheng XL, Wang ZB, Tang CK: Cystathionine gamma-lyase(cse)/hydrogen sulfide system is regulated by mir-216a and influences cholesterol efflux in macrophages via the pi3k/akt/abca1 pathway. Biochem Biophys Res Commun 2016;470:107-116.

57 Rao CY, Fu LY, Hu CL, Chen DX, Gan T, Wang YC, Zhao XY: H2s mitigates severe acute pancreatitis through the pi3k/akt-nf-kappab pathway in vivo. World J Gastroenterol 2015;21:4555-4563. 